\title{
PENGARUH PEMBELAJARAN LARUTAN PENYANGGA MODEL POGIL DAN ADI TERHADAP KETERAMPILAN ARGUMENTASI ILMIAH
}

\author{
Helda Lupita Septyastuti ${ }^{1 *}$, Oktavia Sulistina ${ }^{2}$, Darsono Sigit ${ }^{3}$ \\ 1, 2, 3 Universitas Negeri Malang. Jalan Semarang 5, Malang 65145
}

\begin{abstract}
Abstrak - Penelitian ini bertujuan untuk mengetahui apakah model pembelajaran Argument Driven Inquiry (ADI) memberikan hasil yang lebih baik daripada model pembelajaran Process Oriented Guided Learning (POGIL) terhadap keterampilan argumentasi ilmiah peserta didik pada materi larutan penyangga kelas XI SMAN 2 Nganjuk. Penelitian ini menggunakan rancangan penelitian quasy experimental dengan model penelitian posttest only control group design. Hasil penelitian menunjukkan bahwa model pembelajaran ADI memberikan hasil yang lebih baik daripada model pembelajaran POGIL terhadap keterampilan argumentasi ilmiah peserta didik pada materi larutan penyangga kelas XI SMAN 2 Nganjuk.
\end{abstract}

Kata kunci: ADI, POGIL, keterampilan argumentasi ilmiah

\begin{abstract}
The purpose of this research was to determine whether the implementation of Argument Driven Inquiry (ADI) learning model in the topic of buffer solution gives better results than that of Process Oriented Guided Learning (POGIL) model in term of students' scientific argumentation skills. The sample of this study was XI grade students at SMAN 2 Nganjuk. The study used a quasi experimental research with posttest only controlled group design. The result show that students' scientific argumentation skills who tauhgt using ADI model were better than the skills of those taught using POGIL model.
\end{abstract}

Keywords: ADI, POGIL, scientific argumentation skills

\section{PENDAHULUAN}

Tingkat literasi sains di Indonesia masih rendah dibuktikan dengan peringkat Indonesia pada penilaian PISA berada di urutan 62 dari 70 negara. Hal tersebut disebabkan oleh rendahnya keterampilan argumentasi ilmiah peserta didik. Keterampilan argumentasi ilmiah dalam pembelajaran sains sangat penting karena pembelajaran sains bukan hanya menemukan dan menyajikan fakta tetapi juga berargumen dan mendebat berbagai penjelasan tentang fenomena (Osbone, dkk.; Mc Neill dalam Herlanti, dkk, 2012). Selain itu, sebagai sarana untuk mengkonstruk pemahaman terhadap teori dari suatu konsep yang telah dipelajari sehingga dapat melatih kemampuan kognitif dan afektif peserta didik (Siswanto, 2014).

Analisis kualitas keterampilan argumentasi ilmiah dapat dilakukan dengan menggunakan model SASC (the Structure of Argumentation and Scientific Credibility) dari Puvirajah. Beberapa komponen argumentasi dalam model SASC antara lain claim, evidence dan explanation. Analisis suatu argumen

\footnotetext{
${ }^{*}$ Corresponding authors: Jurusan Kimia, Universitas Negeri Malang, Malang 65145, Indonesia. Email: heldalupitaseptyastuti@gmail.com
} 
tidak cukup hanya dilihat dari kualitas argumen tersebut tetapi validitas ilmiahnya juga harus di evaluasi (Puvirajah dalam Lai, 2012). Maka menurut model SASC, kualitas argumentasi ilmiah ditentukan berdasarkan hubungan antara kualitas struktur argumentasi ilmiah dan kredibilitas ilmiah.

Salah satu pendekatan pembelajaran yang dapat meningkatkan kemampuan argumentasi ilmiah peserta didik adalah pembelajaran dengan pendekatan inkuiri. Model pembelajaran yang dikembangkan berdasarkan pendekatan inkuiri adalah Process Oriented Guided Learning (POGIL). Tahapan pembelajaran dalam model POGIL terdiri dari lima tahapan yaitu (1) orientasi, (2) eksplorasi, (3) konstruksi konsep, (4) aplikasi dan (5) penutup (Hanson, 2005). Pada model pembelajaran POGIL berpusat pada peserta didik (student centered learning) yang memungkinkan peserta didik untuk aktif terlibat dalam berpikir, menganalisis data dan mendiskusikan ide-ide (Yuliastini, 2016) sehingga akan berpengaruh terhadap peningkatan keterampilan argumentasi dan hasil belajar kognitif. Namun, dalam penggunaan model pembelajaran POGIL peserta didik merasa kesulitan bekerja menemukan konsep secara mandiri dan kurang dapat memahami dan menjelaskan konsep dengan baik (Rahayu, 2015). Oleh karena itu, penggunaan model pembelajaran POGIL untuk meningkatkan keterampilan argumentasi masih harus disempurnakan dengan adanya pelatihan argumentasi dalam pembelajaran yang terdapat pada model pembelajaran ADI (Argument Driven Inquiry). Sintaks pembelajaran model ADI terdiri dari 8 tahapan yaitu (1) identifikasi tugas, (2) pengumpulan data, (3) produksi argumen, (4) sesi argumentasi, (5) penyusunan laporan penyelidikan, (6) tinjauan (review) teman sebaya, (7) revisi laporan dan (8) diskusi reflektif. Peserta didik yang menggunakan model pembelajaran ADI memiliki kemampuan yang baik dalam mengidentifikasi masalah, menganalisis data dan memberikan argumen terhadap data tersebut (Enderle dalam Grooms, dkk., 2015).

Salah satu materi kimia yang dapat dibelajarkan menggunakan model pembelajaran POGIL dan ADI adalah materi larutan penyangga. Materi larutan penyangga bersifat konseptual dan merupakan lanjutan dari materi sebelumnya (Dian, 2017). Materi larutan penyangga berisi konsepkonsep dan perhitungan sehingga dibutuhkan pemahaman yang baik, tidak hanya sekedar hafalan. Hal ini menunjukkan bahwa kemampuan argumentasi sangat diperlukan memahami larutan penyangga secara utuh. Hal ini sesuai dengan pendapat McNeil dalam Mumpuni (2016) bahwa "sains bukan hanya menemukan fakta, melainkan membangun argument untuk mempertimbangkannya. Sehingga perlu untuk mengetahui perbedaan pengaruh pembelajaran POGIL dan ADI terhadap kemampuan argumentasi ilmiah peserta didik SMA, khususnya pada materi larutan penyangga.

\section{METODE}

Rancangan penelitian yang digunakan yaitu rancangan penelitian semu (Quasi Experimental) dengan post test only control group design. Rancangan penelitian semu digunakan untuk mengetahui perbedaan keterampilan argumentasi ilmiah peserta didik antara kelas kontrol dan kelas eksperimen. Sebelum kelas eksperimen dan kelas kontrol diberikan perlakuan, dilakukan uji kesamaan rata-rata kemampuan awal peserta didik. Sampel penelitian terdiri dari kelas XI MIPA 4 sebagai kelas kontrol dengan menerapkan model POGIL dan kelas XI MIPA 5 sebagai kelas eksperimen dengan menerapkan model ADI.

Instrumen yang digunakan dalam penelitian meliputi instrumen perlakuan dan instrumen pengukuran. Instrumen perlakuan yang digunakan adalah silabus yang digunakan pada kelas eksperimen dan silabus yang digunakan pada kelas kontrol, rencana pelaksanaan pembelajaran kelas eksperimen dan rencana pelaksanaan pembelajaran kelas kontrol, lembar kerja peserta didik kelas eksperimen dan lembar kerja peserta didik kelas kontrol. Instrumen pengukuran yang digunakan dalam penelitian ini meliputi soal tes keterampilan argumentasi ilmiah. Validitas isi instrumen perlakukan diperoleh kategori sangat baik. Hasil validasi isi instrumen soal tes diperoleh kategori 
sangat baik, dan dari hasil validasi empiris diperoleh hasil validasi butir soal keseluruhan butir soal valid dan memiliki reliabilitas tinggi $(r=0,602)$.

\section{HASIL DAN PEMBAHASAN}

\section{Hasil}

Data keterampilan argumentasi ilmiah peserta didik diperoleh dari nilai ulangan harian pada materi hidrolisis. Data keterampilan argumentasi ilmiah peserta didik dapat dilihat pada Tabel 1. Keterampilan Argumentasi ilmiah peserta didik ditentukan pula dengan hubungan kualitas struktur argumentasi ilmiah dan kredibilitas ilmiah. Data hubungan kualitas struktur argumentasi ilmiah dan kredibilitas ilmiah dapat dilihat pada Tabel 2 dan Tabel 3.

Tabel 1. Deskripsi Nilai Keterampilan Argumentasi Ilmiah Peserta Didik

\begin{tabular}{lccccc}
\multicolumn{1}{c}{ Kelas } & Jumlah Peserta Didik & Nilai Terendah & Nilai Tertinggi & Rata-rata & Standar Deviasi \\
\hline ADI & 31 & 54 & 97 & 82,07 & 11,68 \\
POGIL & 31 & 51 & 94 & 77,26 & 12,52 \\
\hline
\end{tabular}

Tabel 2. Persentase Hubungan Kualitas Struktur Argumentasi Ilmiah dan Kredibilitas Ilmiah Kelas ADI

\begin{tabular}{cccccc}
\hline \multirow{2}{*}{$\begin{array}{c}\text { Tipe Kualitas Struktur } \\
\text { Argumentasi Ilmiah }\end{array}$} & $\begin{array}{c}\text { Tidak } \\
\text { Kredibel }\end{array}$ & $\begin{array}{c}\text { Kredibilitas } \\
\text { Rendah }\end{array}$ & $\begin{array}{c}\text { Kredibilitas } \\
\text { Sedang }\end{array}$ & $\begin{array}{c}\text { Kredibilitas } \\
\text { Tinggi }\end{array}$ & Total \\
\cline { 2 - 5 } I & & & $47,09 \%$ & $47,09 \%$ \\
II & & $6,45 \%$ & $24,52 \%$ & $20,00 \%$ & $21,94 \%$ \\
III & $6,45 \%$ & $26,46 \%$ & $67,09 \%$ & $30,97 \%$ \\
Total & & & $100 \%$ \\
\hline
\end{tabular}

Tabel 3. Persentase Hubungan Kualitas Struktur Argumentasi Ilmiah dan Kredibilitas Ilmiah Kelas POGIL

\begin{tabular}{|c|c|c|c|c|c|}
\hline \multirow[b]{2}{*}{$\begin{array}{l}\text { Tipe Kualitas Struktur } \\
\text { Argumentasi Ilmiah }\end{array}$} & \multicolumn{4}{|c|}{ Kredibilitas Ilmiah } & \multirow[b]{2}{*}{ Total } \\
\hline & $\begin{array}{c}\text { Tidak } \\
\text { Kredibel }\end{array}$ & $\begin{array}{c}\text { Kredibilitas } \\
\text { Rendah }\end{array}$ & $\begin{array}{l}\text { Kredibilitas } \\
\text { Sedang }\end{array}$ & $\begin{array}{c}\text { Kredibilitas } \\
\text { Tinggi }\end{array}$ & \\
\hline $\mathrm{I}$ & & & & $32,26 \%$ & $32,26 \%$ \\
\hline II & & & $5,81 \%$ & $22,58 \%$ & $28,39 \%$ \\
\hline III & & $7,74 \%$ & $31,61 \%$ & & $39,35 \%$ \\
\hline Total & & $7,74 \%$ & $37,42 \%$ & $54,84 \%$ & $100 \%$ \\
\hline
\end{tabular}

Analisis keterampilan argumentasi ilmiah peserta didik digunakan untuk membuktikan bahwa keterampilan argumentasi ilmiah pada kelas eksperimen menghasilkan hasil yang lebih baik daripada kelas kontrol. Analisis data menggunakan uji-t satu pihak dengan bantuan program SPSS 16.0 for windows. Hasil uji-t data keterampilan argumentasi ilmiah peserta didik dapat dilihat pada Tabel 4.

Tabel 4. Hasil Uji- $t$ Data Keterampilan Argumentasi Ilmiah Peserta Didik

\begin{tabular}{|l|c|c|l|}
\hline \multicolumn{1}{|c|}{ Variabel } & Nilai $t_{\text {hitung }}$ & Nilai $t_{\text {tabel }}$ & \multicolumn{1}{c|}{ Kesimpulan } \\
\hline $\begin{array}{l}\text { Keterampilan } \\
\text { argumentasi peserta } \\
\text { didik }\end{array}$ & 2,169 & 1,671 & $\begin{array}{l}\text { Keterampilan argumentasi ilmiah peerta didik pada kelas } \\
\text { eksperimen memberikan hasil yang lebih baik } \\
\text { dibandingkan pada kelas kontrol. }\end{array}$ \\
\hline
\end{tabular}

\section{Pembahasan}

Uji hipotesis keterampilan argumentasi ilmiah peserta didik menunjukkan bahwa keterampilan argumentasi ilmiah peserta didik pada kelas ADI memberikan hasil yang lebih baik daripada kelas POGIL. Hasil uji hipotesis menggunakan uji-t satu pihak menghasilkan thitung lebih besar daripada ttabel $(2,169>1,671)$. Peserta didik yang dibelajarkan menggunakan model ADI memiliki keterampilan argumentasi lebih tinggi $(\bar{x}=82,07)$ dibandingkan yang dibelajarkan menggunakan 
POGIL $(\bar{x}=77,26)$. Berdasarkan hasil analisis kualitas struktur argumentasi ilmiah dan kredibilitas ilmiah menunjukkan bahwa peserta didik pada kelas dengan model ADI lebih banyak mencapai kualitas tertinggi dengan persentase sebesar 47,09\% daripada peserta didik pada kelas POGIL dengan persentase sebesar $32,26 \%$.

Berdasarkan nilai rata-rata argumentasi ilmiah dan kualitas argumentasi ilmiah dari kedua kelas yang tinggi menandakan bahwa model ADI dan POGIL sama-sama memberikan pengaruh yang positif terhadap keterampilan argumentasi ilmiah peserta didik. Model POGIL dapat memberikan pengaruh yang positif terhadap keterampilan argumentasi ilmiah peserta didik karena penerapan model POGIL dapat meningkatkan keterampilan belajar komunikasi dan berpikir kritis yang akan meningkatkan keterampilan argumentasi ilmiah peserta didik (Moog, dkk., 2017). Model ADI terdapat tahap pembelajaran sesi argumentasi yang memberikan kesempatan peserta didik untuk bertukar argumen dengan kelompok lain untuk dapat melatih keterampilan argumentasi ilmiah dan meningkatkan pemahaman terhadap materi yang diajarkan (Sampson, dkk., 2009).

Berbeda dengan langkah pembelajaran pada model pembelajaran POGIL, tidak terdapat langkah pembelajaran sesi argumentasi sehingga peserta didik hanya melatih kemampuan argumentasinya melalui langkah pembelajaran konstruksi konsep. Peserta didik hanya diberikan kesempatan untuk menemukan konsep secara mandiri. Hal ini dimungkinkan menyebabkan keterampilan argumentasi ilmiahnya lebih rendah. Model pembelajaran ADI memberikan hasil yang baik terhadap keterampilan argumentasi ilmiah peserta didik (Marhamah, dkk., 2017). Berdasarkan hasil pemaparan diatas dapat dinyatakan bahwa model ADI memberikan hasil yang lebih baik terhadap keterampilan argumentasi ilmiah peserta didik pada materi larutan penyangga.

\section{KESIMPULAN}

Berdasarkan hasil penelitian dan pembahasan yang telah diuraikan sebelumnya, maka dapat disimpulkan bahwa model ADI memberikan hasil yang lebih baik dibandingkan model POGIL terhadap keterampilan argumentasi ilmiah peserta didik pada materi larutan penyangga kelas XI di SMAN 2 Nganjuk. Jika dilihat dari kualitas argumentasi ilmiah peserta didik, kualitas keterampilan argumentasi tertinggi (struktur argumentasi ilmiah tipe I dan kredibilitas ilmiah tinggi) lebih banyak tercapai pada kelas ADI (47,09\%) daripada kelas POGIL $(32,26 \%)$.

Dari hasil penelitian yang telah dilakukan maka saran yang diberikan adalah dapat dikaji pengaruh model ADI dan model POGIL pada materi lain yang memiliki karakteristik hampir sama dengan larutan penyangga.

\section{DAFTAR RUJUKAN}

Dian, M. A. (2017). Perbedaan Hasil Belajar Kognitif Siswa Kelas XI MLA MAN 1 Malang Yang Dibelajarkan Dengan Model Pembelajaran Inkuiri Terbimbing Kolaboratif dan Inkuiri Terbimbing Non Kolaboratif Pada Materi Larutan Penyangga (Buffer). Skripsi tidak diterbitkan. Malang: Universitas Negeri Malang.

Grooms, J., Enderle, P., \& Sampson, V. (2015). Coordinating Scientific Argumentation and the Next Generation Science Standards through Argument Driven Inquiry. Journal Science Educator 24(1), 45-50. Dari

Herlanti, Y., Rustaman, N.Y., Rohman, I., \& Fitriani, A. (2012). Kualitas Argumentasi Pada Diskusi Isu Sosiosaintifik Mikrobiologi melalui Weblog. Jurnal Pendidikan IP A Indonesia 1(2), 168-177.

Lai, M. C. (2012). Nature of Science Knowledge and Scientific Argumentation Skills in Taiwanese College Biology Students. Doctoral dissertation. Columbus: Ohio State University (Online),

Marhamah, O. S., Nurlaelah, I. \& Setiawati, I. (2017). Penerapan Model Argument-Driven Inquiry (ADI) dalam Meningkatkan Kemampuan Berargumentasi Siswa pada Konsep Pencemaran Lingkungan di Kelas X SMA Negeri 1 Ciawigebang. Quagga (9) 46-53.

Moog, R. S., Dubroff, M., Boldizar, J., Cook, P., Ferguson, R., Harpel, E., Miller, B., Rathmell, S., Ressel, E., Wilson, S., \& Straumanis, A. Pogil. (Online), (https://pogil.org/about-pogil/what-is-pogil), diakses 1 November 2017. 
Mumpuni, I.P. (2017). Analisis Keterampilan Argumentasi Ilmiah Peserta Didik SMAN 1 Singosari ditinjau dari Klasifikasi Program Semester pada Sub Materi Sifat Periodik Unsur. Sripsi tidak diterbitkan. Malang: Universitas Negeri Malang.

Rahayu, D.P \& Pamelasari, S.P. (2015). Pengaruh Model Pembelajaran Process Oriented Guided Inquiry Learning Terhadap Kemampuan Berpikir Kritis Peserta Didik Pada Materi Perubahan Benda. Unnes Science Education Journal, 4(3): 936-944.

Sampson, V., Grooms, J., \& Walker, J. (2009). Argument-Driven Inquiry to promote learning during laboratory activities. The Science Teacher, 76(7), 42-47.

Siswanto, Kaniawati, I. \& Suhandi, A. (2014). Penerapan Model Pembelajaran Pembangkit Argumen Menggunakan Metode Saintifik Untuk Meningkatkan Kemampuan Kognitif dan Keterampilan Berargumentasi Siswa. Jurnal Pendidikan Fisika Indonesia, 10(2): 104-116.

Yulistiani, I.B, Rahayu. S \& Fajaroh, F. (2016). POGIL Berkonteks Socio Scientific Issues (SSI) dan Literasi Sains Siswa SMK. Makalah disajikan dalam Seminar Nasional Pendidikan IPA Pascasarjana UM , Pendidikan IPA Pascasarjana UM, Malang, 8 Oktober. 